University of Nebraska - Lincoln

DigitalCommons@University of Nebraska - Lincoln

Papers in the Earth and Atmospheric Sciences Earth and Atmospheric Sciences, Department

October 2002

\title{
Early Deglaciation in the Tropical Andes
}

G. O. Seltzer

Syracuse University

D. T. Rodbell

Union College, Schenectady, NY

P. A. Baker

Duke University, pbaker@duke.edu

Sherilyn C. Fritz

University of Nebraska-Lincoln, sfritz2@unl.edu

P. M. Tapia

University of Nebraska-Lincoln

See next page for additional authors

Follow this and additional works at: https://digitalcommons.unl.edu/geosciencefacpub

Part of the Earth Sciences Commons

Seltzer, G. O.; Rodbell, D. T.; Baker, P. A.; Fritz, Sherilyn C.; Tapia, P. M.; Rowe, H. D.; Dunbar, R. B.; and Clark, Peter U., "Early Deglaciation in the Tropical Andes" (2002). Papers in the Earth and Atmospheric Sciences. 10.

https://digitalcommons.unl.edu/geosciencefacpub/10

This Article is brought to you for free and open access by the Earth and Atmospheric Sciences, Department of at DigitalCommons@University of Nebraska - Lincoln. It has been accepted for inclusion in Papers in the Earth and Atmospheric Sciences by an authorized administrator of DigitalCommons@University of Nebraska - Lincoln. 


\section{Authors}

G. O. Seltzer, D. T. Rodbell, P. A. Baker, Sherilyn C. Fritz, P. M. Tapia, H. D. Rowe, R. B. Dunbar, and Peter U. Clark 


\section{Early Deglaciation in the Tropical Andes}

The record of ancient glaciers is the principal source of information on high-altitude paleoclimate in the tropics, but the age of late Pleistocene glaciation throughout the tropics is poorly constrained, which complicates estimating past climate from glacial records. Seltzer et al. (1) established that maximum late Pleistocene glaciation in the tropical Andes was broadly synchronous with the global Last Glacial Maximum (LGM) 21,000 calendar years before present (cal yr B.P.), which supports inferences of LGM cooling of $4^{\circ}$ to $6^{\circ} \mathrm{C}$ at high altitudes in the tropics (2). Comparing their records to a record of glaciation in the Sierra Nevada and to Greenland and Antarctic ice core records, Seltzer et al. also concluded that deglaciation in the tropical Andes preceded substantial post-LGM warming at high northern latitudes by several thousand years, which in turn led them to speculate that earlier warming in the tropics triggered the last deglaciation. Here, I show that the Sierra Nevada record of glaciation is inappropriate for comparison with the Andean records used by Seltzer et al. and that a number of other well-dated records of Northern Hemisphere glaciation have an early-deglaciation phase at the same time as that of the tropical Andes. I also show that different published chronologies of Greenland and Antarctic ice-core records lead to different conclusions on the relationship between high-latitude climate change and that of the tropical Andes.

Seltzer et al. dated tropical deglaciation based on proxies in Lake Junin, Peru, and Lake Titicaca, Peru/Bolivia. Nearby LGM glaciers supplied the lakes with sediment, but retreat of the glaciers resulted in the formation of lakes behind the LGM moraines that trapped glaciogenic sediments. This sediment trapping not only amplified the deglacial signal in lakes Junin and Titicaca, but also attenuated any subsequent evidence of continued glaciation in the watersheds. Their lake records thus cannot reveal the magnitude of glacier retreat. Indeed, other work on the glacial history of this region suggests that late Pleistocene glaciers were near their LGM limit at $17,550 \pm 300$ cal yr B.P. and at $\sim 50 \%$ of LGM size $\sim 16,650$ cal yr B.P. (3), but in general the details of deglaciation remain poorly understood.

Seltzer et al. compared their records with a record of Sierra Nevada glaciation from Owens Lake, California (4), to argue that tropical deglaciation occurred several thousand years before Northern Hemisphere deglaciation. In contrast to those of Junin and Titicaca, however, retreat of LGM Sierran glaciers did not result in similar sediment trapping in moraine-dammed lakes; thus, Owens Lake continued to receive glaciogenic sediment as long as the watershed remained glaciated. Consequently, the South American lake records should not be directly compared with those from Owens Lake to contrast the timing of deglaciation. More appropriate comparisons to Northern Hemisphere deglaciation should be based on records that directly date the timing of ice-margin fluctuations. Several such records from western North America reveal that an early deglacial phase occurred at the same time as that of the tropical Andes (Fig. 1A). Similar ages of deglaciation are also suggested for sectors of the Laurentide (5), British (6), and Scandinavian (7) ice sheets. Early deglaciation following the LGM thus was not unique to the tropical Andes.

By comparing the timing of tropical Andean deglaciation to methane-synchronized ice-core records of temperature from Greenland (GRIP) and Antarctica (Byrd Station) placed on the GRIP time scale (8), Seltzer et al. concluded that "the onset of deglaciation in the tropical Andes follows the record of Antarctic warming." However, the GRIP time scale used by
Seltzer et al. is younger than the GISP2 time scale (9) for ages $>15,000$ yr B.P. Recent highresolution dating of a Chinese speleothem supports the GISP2 time scale (10), and Johnsen et al. (11) revised the GRIP time scale so that it now agrees with GISP2 back to 40,000 yr B.P. The methane-synchronized ice-core records on the GISP2 timescale $(12,13)$ show that initial warming at Greenland began $\sim 24,000$ yr B.P., 2000 to 3000 years before Antarctic and tropical warming, and that nearly one-third of deglacial warming had occurred by 19,000 yr B.P., well before the onset of the Bølling-Allerød warming (14) (Fig. 1). In contrast, the ice-core record shows no change in atmospheric methane concentration during this time (Fig. 1A), which suggests that the climate change responsible for early tropical deglaciation was insufficient to affect low-latitude methane source regions.

In summary, the onset of tropical Andean deglaciation from LGM positions occurred at the same time as deglaciation widely recorded at higher northern latitudes, in contrast to the conclusion by Seltzer et al. that tropical warming led and thus caused Northern Hemisphere deglaciation. The timing of this early phase of deglaciation was coincident with high-latitude warming and increased summer insolation in the
Fig. 1. Climate records spanning the last deglaciation. The vertical gray box represents the timing of tropical deglaciation established in (1). (A) The GISP2 record of atmospheric methane $(12,13)$. Also shown are the ages of deglaciation from five glacier systems in western North America (no vertical scale). WR, weighted mean $(20,100 \pm 1000$ yr B.P.) of ${ }^{10} \mathrm{Be}$ ages on boulders from LGM moraine in the Wind River Mountains, Wyoming (15). $\mathrm{SN}$, weighted mean $(21,000 \pm$ $3000 \mathrm{yr}$ B.P.) of ${ }^{36} \mathrm{Cl}$ ages on boulders from the LGM moraine in the Sierra Nevada Mountains, California $(16,17)$. I interpret these cosmogenic surface exposure ages as representing landform age, and thus the time since the moraine was last occupied. OM, weighted mean $(22,800 \pm 100 \mathrm{yr}$ B.P. $)$ of calibrated ${ }^{14} \mathrm{C}$ ages on organics from lake sediments directly above till associated with a moraine in the Olympic Mountains, Washington (18). CIS, weighted mean $(22,100+100$ yr B.P.) of calibrated ${ }^{1 \overline{4}} \mathrm{C}$ ages on organics directly above glacial sediments associated with an advance of the southern margin of the Cordilleran Ice Sheet into the Fraser Lowlands, British Columbia (19). YIC, weighted mean $(22,400 \pm 100 \mathrm{yr}$ B.P.) of U-series ages on travertine associated with reduced ice cover in the valley occupied by the northern outlet glacier of the Yellowstone Ice Cap (20). (B) Smooth curves: midmonth insolation at $60^{\circ} \mathrm{N}$ for June and at $30^{\circ} \mathrm{S}$ for December (21). Jagged curves: GISP2 record of oxygen isotopes. Gray line represents high-resolution, bidecadal data published by Stuiver and Grootes (9); black line represents lower resolution data published by Grootes et al. (22). (C) Byrd Station record of oxygen isotopes on GISP2 time scale $(12,13)$. 
Northern Hemisphere (Fig. 1), a coincidence that supports arguments for high-latitude forcing of the deglaciation (14).

Peter U. Clark

Department of Geosciences Oregon State University Corvallis, OR 97331, USA E-mail: clarkp@ucs.orst.edu

\section{References and Notes}

1. G. O. Seltzer et al., Science 296, 1685 (2002).

2. S. W. Hostetler, P. U. Clark, Science 290, 1747 (2000).

3. A. Y. Goodman, D. T. Rodbell, G. O. Seltzer, B. G. Mark, Quat. Res. 56, 31 (2001).

4. L. V. Benson et al., Science 274, 746 (1996).

5. A. S. Dyke et al., Quat. Sci. Rev. 21, 9 (2002).

6. A. M. McCabe, P. U. Clark, Nature 392, 373 (1998).

7. T. O. Vorren, K.-D. Vorren, T. Alm, S. Gulliksen, R. Lovlie, Boreas 17, 41 (1988).

8. T. Blunier et al., Nature 394, 739 (1998).

9. M. Stuiver, P. M. Grootes, Quat. Res. 53, 277 (2000).

10. Y. J. Wang et al., Science 294, 2345 (2001).

11. S. J. Johnsen et al., J. Quat. Sci. 16, 299 (2001).

12. T. Blunier, E. J. Brook, Science 291, 109 (2001).

13. The small changes in methane between 18,000 and $24,000 \mathrm{yr}$ B.P. lead to relatively large uncertainties in the correlation between Greenland and Antarctic ice cores.

14. R. B. Alley, E. J. Brook, S. Anandakrishnan, Quat. Sci. Rev. 21, 431 (2002)

15. J. C. Gosse, J. Klein, E. B. Evenson, B. Lawn, R. Middleton, Science 268, 1329 (1995)

16. F. M. Phillips et al., Science 274, 749 (1996).

17. F. M. Phillips, personal communication.

18. G. D. Thackrey, Quat. Res. 55, 257 (2001).

19. S. R. Hicock, O. B. Lian, Can. J. Earth Sci. 32, 758 (1995).

20. N. C. Sturchio, K. L. Pierce, M. T. Murrell, M. L. Sorey, Quat. Res. 41, 265 (1994).

21. A. Berger, IGBP PAGES/World Data Center-A for Paleoclimatology Data Contribution Series \# 92-007, NOAA/NGDC Paleoclimatology Program, Boulder, CO, USA (1992).

22. P. M. Grootes, M. Stuiver, J. W. C. White, S. J. Johnsen, J. Jouzel, Nature 366, 552 (1993).

18 June 2002; accepted 2 August 2002

Response: Analysis of sediment records from lakes located beyond the glacial limit in the Andes has provided, for the first time, an independent assessment of effective moisture (precipitation minus evaporation) and the timing of the last glaciation (1). Conditions were wet at the LGM and remained so until approximately 15,000 cal yr B.P. (2). However, deglaciation was under way from the LGM between 22,000 and 19,500 cal yr B.P., which reinforces the observation that deglaciation in the tropical Andes was primarily forced by an increase in mean annual temperature during a wet postglacial interval $(3,4)$.

Clark presents three main criticisms of the comparisons of the Andean glacial record (1) with records of deglaciation and climate change in the Northern Hemisphere. First, he questions the appropriateness of comparing lacustrine records of deglaciation from lakes Titicaca and Junin with the record of deglaciation in the Sierra Nevada from Owens Lake (5). Second, he asserts that several localities in the Northern Hemisphere show an early deglaciation similar to that of the tropical Andes. And, third, he argues that the isotopic record from the Greenland ice cores indicates warming between 24,000 and 19,000 cal yr B.P. that may account for as

\section{TECHNICALCOMMENTS}

much as one-third of the last glacial-interglacial warming. Clark uses these observations to conclude that global deglaciation, and presumably warming, were synchronous at the end of the LGM and were forced by changes in the Northern Hemisphere high latitudes.

Owens Lake, California, is one of the few lake basins in North America that lies immediately beyond the limit of late Quaternary glaciers, and it has provided a continuous record of glaciation of the eastern Sierra Nevada (5). In this sense, the lake provides an analogous setting to lakes Titicaca and Junin in the tropical Andes and constitutes an apt comparison with them. However, Clark contends that such a comparison is inappropriate because morainedammed lakes formed behind LGM moraines in the tropical Andes, whereas no such setting was found in the Owens Lake catchment. The observation that sediment trapping by proglacial lakes may not have occurred in the Sierra Nevada until after around $14,500 \mathrm{cal}$ yr B.P. is important. However, the published glacial chronologies from Bloody Canyon and other sites on the eastern side of the Sierra Nevada indicate that glaciers were within $\sim 1$ to $2 \mathrm{~km}$ of the LGM limit, or re-advanced to that position, until the Tioga 4 Glaciation, around 16,000 \pm 1000 yr B.P. (6). Thus, the record of glaciation as represented by the lacustrine sequences from the Andes and the eastern side of the Sierra Nevada shows marked differences that relate directly to the glacial history of these regions and presumably to regional warming following maximum glaciation. Furthermore, based on our previous work and that of others in the tropical Andes, it is known that late-glacial stillstands or readvances punctuated glacial retreat from the LGM between around 16,000 and 13,000 cal yr B.P., but ice limits during the same period were as much as $50 \%$ less extensive than during the LGM (7-11). Deglaciation was thus comparatively rapid in the tropical Andes, whereas conditions conducive to extensive glaciation were maintained or recurred into the late-glacial in the Sierra Nevada.

Clark also points out that sites exist in the Northern Hemisphere that show evidence of early deglaciation, similar to what we reported for the tropical Andes. Clark presumes that these examples of early deglaciation in the Northern Hemisphere resulted from the warming that is documented by a change in temperature over Greenland as early as 24,000 yr B.P. (12), and not by a local reduction in moisture balance. In any case, cosmogenic exposure ages may date the time of glacier equilibrium during full glacial conditions (6) and do not necessarily denote the onset of deglaciation, as implied by Clark. In addition, well-dated records from the southern margin of the Laurentide Ice Sheet and from the St. Elias Mountains [summarized in (13)] reveal that ice extents were at maxima or nearly so until as late as around $16,000 \mathrm{cal}$ yr B.P. This, again, differs strikingly from the best-dated records from the tropical Andes.

Clark notes that significant warming between 24,000 and $19,000 \mathrm{cal}$ yr B.P. is recorded in stable isotopes from the Greenland ice cores, and that this warming was synchronous with, if not slightly earlier than, that observed from Antarctica. The important difference between the Greenland and Antarctic records is that warming was not sustained over Greenland during the period from around 24,000 to $14,500 \mathrm{cal} \mathrm{yr} \mathrm{B.P.,}$ whereas the best-dated evidence from the tropical Andes indicates that warming did continue during that interval. In this sense, the tropical Andean record is more like the isotopic record from Antarctica than that from Greenland. The relatively rapid deglaciation in the tropical Andes was forced by an increase in mean annual temperature, and we suggest that this sustained warming in the tropics may have had a significant impact on deglaciation in the Northern Hemisphere.

G. O. Seltzer

Department of Earth Sciences Syracuse University Syracuse, NY 13244, USA E-mail: goseltze@syr.edu

D. T. Rodbell

Department of Geology Union College

Schenectady, NY 12308, USA

P. A. Baker

Nicholas School of the Environment and Earth Sciences

Duke University

Durham, NC 27708, USA

S. C. Fritz

P. M. Tapia

Department of Geosciences and School of Biological Sciences University of Nebraska Lincoln, NE 68588, USA

H. D. Rowe R. B. Dunbar Department of Geological and Environmental Sciences Stanford University Stanford, CA 94305, USA

References and Notes

1. G. O. Seltzer et al., Science 296, 1685 (2002).

2. P. A. Baker et al., Science 291, 640 (2001).

3. A. G. Klein et al., Quat. Sci. Rev. 18, 63 (1999).

4. S. W. Hostetler, P. U. Clark, Science 290, 1747 (2000).

5. L. V. Benson et al., Science 274, 746 (1996).

6. F. M. Phillips et al., Science 274, 749 (1996).

7. J. H. Mercer, M. O. Palacios, Geology 5, 600 (1977).

8. J. H. Mercer, in J. C. Vogel, Ed., Late Cainozoic Paleoclimates of the Southern Hemisphere (Balkema, Rotterdam, 1984), pp. 45-58.

9. J. D. Clayton, C. M. Clapperton, J. Quat. Sci. 12, 169 (1997).

10. D. T. Rodbell, G. O. Seltzer, Quat. Res. 54, 328 (2000).

11. A. Y. Goodman et al., Quat. Res. 56, 31 (2001).

12. R. Alley, E. Brook, S. Anandakrishnan, Quat. Sci. Rev. 21, 431 (2002).

13. W. S. Broecker, G. H. Denton, Geochim. Cosmochim. Acta 53, 2465 (1989).

14. We acknowledge the U.S. NSF Earth System History program for ongoing support of this research.

3 July 2002; accepted 17 September 2002 